Page $159-176$

\title{
THE MOTIVATION OF MUZAKKI TO PAY ZAKAH: STUDY AT THE BAITUL MAL ACEH
}

\author{
M. Shabri Abd. Majid \\ Syiah Kuala University \\ mshabri@unsyiah.ac.id
}

\begin{abstract}
This study empirically explores the factors motivating Muzakki (zakat payers) to pay zakat at the Baitul Mal Aceh, Indonesia. The factors motivating Muzakki to pay zakat investigated in the study comprises culture, regulation, motivation, and Muzakki understanding on zakat. 600 questionnaires were disseminated to the respondents, which were selected based on the convenience sampling technique. Then, the data were analysed using a binary logistic regression. The results of this study showed that culture, regulation, motivation, and understanding of the Muzakki on zakat significantly and positively affected the decision of Muzakki to pay their zakat at the Baitul Mal Aceh. This study implies that in order Muzakki to pay their zakat at the Baitul Mal, Islamic cultures should be preserved among Achenese, government should enhance regulation pertaining zakat management and the people of Aceh need to be equipped with the relevant knowledge on the obligation of zakat payment.
\end{abstract}

Keywords: zakah, baitul mal, muzakki, logistic regression, Aceh.

\begin{abstract}
Abstrak
Penelitian ini bertujuan untuk mengeksplorasi secara empiris pengaruh budaya, regulasi, motivasi, dan pengetahuan tentang zakat para Muzakki terhadap keputusan Muzakki untuk membayar zakat di Baitul Mal Aceh, Indonesia. 600 kuesioner telah disebarkan kepada para responden, yang dipilih berdasarkan teknik convenience sampling. Data yang terkumpul telah dianalisis dengan menggunakan regresi berganda logistik biner. Hasil penelitian ini menunjukkan bahwa budaya, regulasi, motivasi, dan pengetahuan tentang zakat berpengaruh positif dan signifikan terhadap keputusan Muzakki untuk membayar zakat di Baitul Mal. Hasil penelitian ini berimplikasi bahwa dalam rangka menjadikan Baitul Mal sebagai tempat plihan para Muzakki untuk membayar zakat mereka, maka budaya Islam di Aceh harus dipertahankan, pemerintah harus memperkuat regulasi terkait pengelolaan zakat termasuk aturan tentang zakat sebagai pengurang pajak, dan pengetahuan tentang zakat meliputi nisab, haul, asnaf, jenis-jenis zakat dan pengetahuan relevan lainnya tentang kewajiban berzakat harus ditingkatkan dan disosialisasikan.
\end{abstract}

Kata Kunci: zakat, bailtul mal, muzakki, regresi logistik, Aceh.

Received: November 19, 2016; Revised: January 10, 2017; Approved: January 20, 2017 
The Motivation of Muzakki...

M. Shabri Abd. Majid

\section{INTRODUCTION}

With issuance of the PSAK (Pernyataan Standar Akuntansi Keuangan - Financial Accounting Standard Statement) No. 109 of 2008 on the Zakat and Charity Accounting, zakat has become one of sources of the Indonesian national income. The enactment of the PSAK warmly welcomed by many Muslims in the country, especially the religious leaders and Islamic organizations. Moreover, if we look at the history of Islam during the Prophet Muhammad (pbuh) era and even at the period of the earlier Prophets in Islamic history, Almighty God has obliged the Muslims to pay zakat. Allah the Exalted said in the Holy Qur'an, Surah al-Baqarah,Verse I I0:

"And establish prayer and give zakat, and whatever good you put forward for yourselves - you will find it with Allah. Indeed, Allah is watching everything you do".

As it well known among Muslims, zakat is the fourth pillar of Islam, which is a condition to be a Muslim for those who has been able to pay zakat. To regulate management of zakat in Indonesia, the Government has enacted the Law No. 38 of 1999 that provided authority for BAZ (Government Zakah Institution) and LAZ (Private Zakah Institution) to manage zakat in Indonesia. Of 34 provinces in Indonesia, Aceh is the only province that has been granted by the central government of Indonesia to implement autonomously the Islamic law in accordance with the legislation No. 44 of 1999; and the Provincial Regulation No. 5 of 2000 on the implementation of Islamic law. These acts provided the privileges for the government of Aceh to manage zakat autonomously.

Previous studies showed that Indonesia had a huge potential of zakat to contribute to the national income. Approximately, it reached $2 \%$ of the national GDP (Gross Domestic Product), amounting Rp2I7 trillion per year (Firdaus et al., 2012). In Aceh, the zakat potential reached RpI.4 trillion annually. Unfortunately, the realization of zakat collection in the province of Aceh was only $1.45 \%$ during the last five years (Central Beaureu of Statistics, Aceh Province, 2015). If this zakat potential can be materialised optimally, it could serve as an effective measure to combat poverty in the region (Suma, 20I3).

It has been not only the problem faced by Baitul Mal in Indonesia but also in Aceh where the Baitul Mal has only collected zakat very far from its potential. Why did this happen? Whether is it caused by the lower performance of the Baitul Mal alone? 
Or are there other factors such as the Muzakki preferences not to pay zakat at the Baitul Mal? Previous related studies on zakat conducted in other cities in Indonesia and Malaysia have identified several factors affecting the level of zakat collection, including factors of culture, motivation, regulation, and understanding of the zakat by Muzakki. The extent to which, these factors have effects on the decision of Muzakki to pay zakat at Baitul Mal?

In view of the above background, thus, this study purposely examines factors influencing the motivation of Muzakki to pay Zakat al-Mal at the Baitul Mal Aceh. Particularly, it attempts to empirically explore the influences of culture, motivation, regulation, and knowledge of Muzakki about zakat on their zakat payment at the Baitul Mal Aceh, Indonesia. The rest of this study is structured as follows. Section 2 reviews previous selected studies on zakat. Section 3 highlights the data utilised and empirical model of analysis. Section 4 presents the empirical results and discussions. At last, Section 5 concludes the paper.

Quoted the Holy Qur'an Surah Al-Fathir, Verse 18, and Al-Kahfi Verse 74, Asmuni (2007) provided the meaning of the word zakat etymologically, as: (I) increasing or doubling, (2). Growing and expanding, (3) sacred or innocent, (4) sanctifying oneself, and (5) praising good. According to the IAI (Ikatan Akuntan Indonesia- Indonesian Accountant Association) (2008: 109.3) in PSAK No. 109, zakat is a treasure that must be paid by Muzakki in accordance with the provisions of Shariah to be given to those who deserve it (Mustahik). Muzakki is a Muslim who obliges to pay zakat, while Mustahik is a person or entity entitled to receive zakat. Nisab is the minimum threshold required for the zakat issuance by Mustahik (IAI, 2008: 109.2109.3, in the PSAK, No. 109).

In Islam, the zakat payment is one of the means for Muslims to purify their wealth from prohibited sources of income. Zakat is a religious obligation that has socio-economic implication, and it is a part of monetary and social system of Islam that empower and harmonize the people's welfare (Rais, 2009). Thus, zakat is closely linked to the issue of just income distribution system (Rahmawati, 20II). It also contains the economic implication, which the zakat payment will uplift the poor (Mustahik) from starvation. Zakat causes the multiplier effect on promoting the eonomic welfare (Arif, 2012) and economic prigress (Nurhasanah, 20I2). It can cleanse the 
The Motivation of Muzakki...

M. Shabri Abd. Majid

liver from avarice and love of the world and fosters kindness and to gain more wealth. Thus, the Muslim oblige to pay zakat with a full consciousness, as it is not only to perform obligation, but it also provide monetary assistance for the needy. Although, Islam allows zakat to be paid personally and directly by Muzakki to the Mustahik, but Islam highly encourages the zakat to be paid through the zakat institutions. Paying zakat through the zakat institutions has more advantageous, such as creating effectiveness of zakat management, avoiding double recipient of zakat by Mustahik, initiating the proper zakat collection and distribution mechanism, and fostering the poverty reduction.

It is strongly believed that one of the reasons of why the realization of zakat collection is still far from its potentiality is simply due to the reluctance of Muzakki to pay zakat through the zakat institutions. Therefore, when the Muzakki pay zakat personally and directly to the Mustahik, it is difficult to record. Thus, identifying the motivation of the Muzakki to pay zakat via Baitul Mal is extremely important.

In an Islamic perspective, the behaviour of Muslim is based on several assumptions, namely: (I) Islam is a religion that is applied in society; (2) zakat is obligatory; (3) there should be no usuary (riba) in society; (4) the principle of profitsharing (Mudharabah) is applied in business activity; (5) individual behaves rationally to maximise satisfaction. Additionally, Daud et al. (20II) identified seven factors affecting the obedience of Muslim to pay zakat that are implementation of legislation, commitment to religion, knowledge, ease of payment mechanism, trust in institutions, perceptions of the tax system, and environmental factors.

Furthermore, according to Daud et al. (20II), environmental factor could be further grouped into two types, i.e., internal and external factors of the individual. Thus, motivations of an individual to pay zakat are considered as the internal factors, while the cultures where the individual living are categorised as the external factors in this study. Apart from these two factors, regulation and understanding of zakat are also found to affect the willingness of Muzakki to pay zakat (Jahrotunasipah, 2012). Ahira (2013) stated that culture is everything related to the mind or intellect and everything produced by the mind or the intellect, and it also relates to work, taste, and creative community. 
As far as the measurement of motivation is concerned, Danim (2004) identified several indicators, namely strength, motive, encouragement, needs, spirit, pressure, or psychological mechanisms that encourage a person or group of people to achieve specific achievements in line with what he wanted. Huitt (200I) added that motivation could be measured by an internal condition or status (sometimes interpreted as the needs, wants, or desires) that directs the behaviour of people to actively act in order to achieve a certain goal. As stated earlier, regulation is also one of the factors affecting people willingness to pay zakat. The priority of zakat management should also be regulated (Huda et al., 2014) to ensure that the zakat could be an effective measure to promote the welfare of the poor. Regulation compels and determines human behaviour in a community environment created by official bodies' authorities, where the breach of the rules had resulted in penalty (Daliyo et al., 200I).

The last factor affecting the zakat payment examined in this study is the understanding of zakat. Understanding of the zakat is a religious teaching of Islam, in the context of worship to the divine injunction and, in the context of humanity (Muamalah), zakat is seen as a phenomenon instrument of liberation and justice (Malik, 20I0). Meanwhile, Sahlan (20II) stated that understanding of zakat comprises the zakat related issues of nisab of zakat, alms haul, types of zakat, zakat calculation, collection, distribution and penalty to those who do not pay zakat.

\section{METHOD}

This study empirically explores the influences of culture, motivation, regulation and knowledge on the zakat payment by Muzakki at the Baitul Mal Aceh, Indonesia. For this purpose, this study selected 600 respondents who are domiciled in Aceh based on the simple random techniques. Out of 600 respondents, 300 of them have experienced of paying zakat at the Baitul Mal, Aceh and the rest 300 who have no experienced of paying zakat at the Baitul Mal Aceh with a different backgrounds, including civil servants, private employees, traders and other workers.

All 600 questionnaire consisting 32-question distributed to the respondents were returned and completely filled up. One questions was asked about Muzakki motivation either to pay or to not pay zakat at the Baitul Mal, 6-question were asked 
The Motivation of Muzakki...

M. Shabri Abd. Majid

pertaining to the culture, 5-question were asked relating to the motivation and regulation, respectively. Finally, 15 questions were posted relating to knowledge or understanding of Muzakki on zakat obligation.

In a more detail, the willingness of Muzakki to pay zakat (PZ) was computed by their willingness or unwillingness to pay zakat at the Baitul Mal. Culture (CUL) was measured by several indicator, such as: knowledge, belief, art, morals, law, and customs. These six indicators were measured using an interval scale with a six-item statement. Motivation (MOT) measured by five indicators of strength, motive, need, encouragement, and pressure (Danim, 2004). These indicators were measured using an interval scaled with a five-item statement. Next, regulation (REG) was measured by five indicators (statements) comprising force, rule the human behaviour, created by official bodies, should be adhered to and give strict punishment (Daliyo, 200I). Finally, the knowledge of understanding of zakat $(K Z)$ was measured by fifteen indicators comprising the knowledge on zakat obligation, nisab, alms haul, type of zakat, calculation, collection, distribution, and the penalty for those who do not pay zakat (Sahlan, 20II). With the exception of the variable of willingness to pay zakat at the Baitul Mal, which was measured using a nominal scale, all other variables were measured using interval scale. All the questions or statements were answered in the following Likert-Scale categories, namely: strongly agree - SA (score = 5), Agree - A $($ score $=4)$, undecided - UD (score = 3), disagree - DA (score $=2$ ), and strongly disagree - SD (score = I).

In order to ensure the accuracy and consistency of the data, before the indicators are further measured and analysed, the validity and reliability tests were performed. Additionally, the classical assumptions of normality, multicollinearity, and heteroscedasticity were also tested using the standardised techniques.

Following the instruments and classical assumption tests, all the measured variables would be tested using the logistic regression to identify the influences of culture, motivation, regulation and knowledge on the willingness of Muzakki to pay zakat at the Baitul Mal, Aceh. The logistic regression is the most suitable model of estimation to be adopted in this study, since the value of dependent variable was measured in the ordinal scale (with value 0 or I), while the dependent variables were 
in measured in the interval scale (with values I, 2, 3, 4, and 5). The following multiple logistic regression was tested.

$$
\text { Logit }(P / I-P)=\beta_{0}+\beta_{1} X_{1}+\beta_{2} X_{2}+\beta_{3} X_{3}+\beta_{4} X_{4}+e
$$

Where $p$ is the probability that $Y$ is equal to $I$, and $X_{1}, X_{2}, X_{3}$, and $X_{4}$ are the independent variables, and $\beta_{\mathrm{i}}$ is the estimated regression coefficient. Logistic regression will form the predictor variable/response $(\log (p /(I-p))$, which is a linear combination of the independent variables. Value of predictor variables is then transformed into a probability with logistic function, so that the logistic model in this study could be rewritten as follows:

$$
\text { Logit }(\mathrm{P})=\mathrm{PZ}=\mu_{0}+\mu_{1} \mathrm{BUD}+\mu_{2} \mathrm{MOT}+\mu_{3} \mathrm{REG}+\mu_{4} \mathrm{KZ}+\mathrm{e}
$$

Where PZ is the willingness to pay zakat at the Baitul Mal (Pay = I; do not pay $=0) ; \mu_{0}$ is a constant term, BUD is the variable of culture; MOT is the variable of motivation; REG is the variable of regulation; and $\mathrm{KZ}$ is knowledge or understanding on zakat; $\mu_{i}$ are the estimated coefficients of BUD, MOT, REG and KZ; and $e$ is the error term.

\section{RESULTS AND DISCUSSION}

Table I showed the characteristics of 600 randomly selected respondents of the study. In terms of gender, 49.5 percent of the respondents were male, and $50.5 \%$ of them were female. Majority of them were with age of more than 40 years old and married (72.0). Only $4.0 \%$ and $3.3 \%$ were widow and widowed, respectively. With regards to the educational background, majority of them were with bachelor degree (55.1\%), followed by Senior High School (21.3\%). Only 2.7\% and I.7\% were the PhD holder and Primary School graduates, respectively.

In terms of the respondents' job, more than half $(52.0 \%)$ were the government employees and minority of them were the traders or businessmen. $50.5 \%$ respondents earned monthly fixed income of Rpl-3 million, and only $4.9 \%$ and $7.0 \%$ earned more than $\operatorname{Rp} 7$ million and less than Rp I million, respectively. However, in terms of monthly non-fixed income, most of them (5I.2\%) earned only less than $R p$ I million, I.8\% earned $R p$ 5-7 million, and I.2\% earned more than Rp7 million.

Table 2 portrayed the respondents' answers on whether they have experienced of paying zakat through Baitul Mal or have not. 300 respondents acknowledged that 
The Motivation of Muzakki...

M. Shabri Abd. Majid

they have paid zakat via Baitul Mal, and 300 others said that they have not. As mentioned earlier, the study purposely selected $50 \%$ of the respondents have paid zakat via Baitul Mal and the other $50 \%$ have no experienced of paying zakat via Baitul Mal so that the finding of the study would proportionately represented factors affecting the Muzakki to pay or not pay zakat via Baitul Mal.

Table I: Characteristics of the Respondents

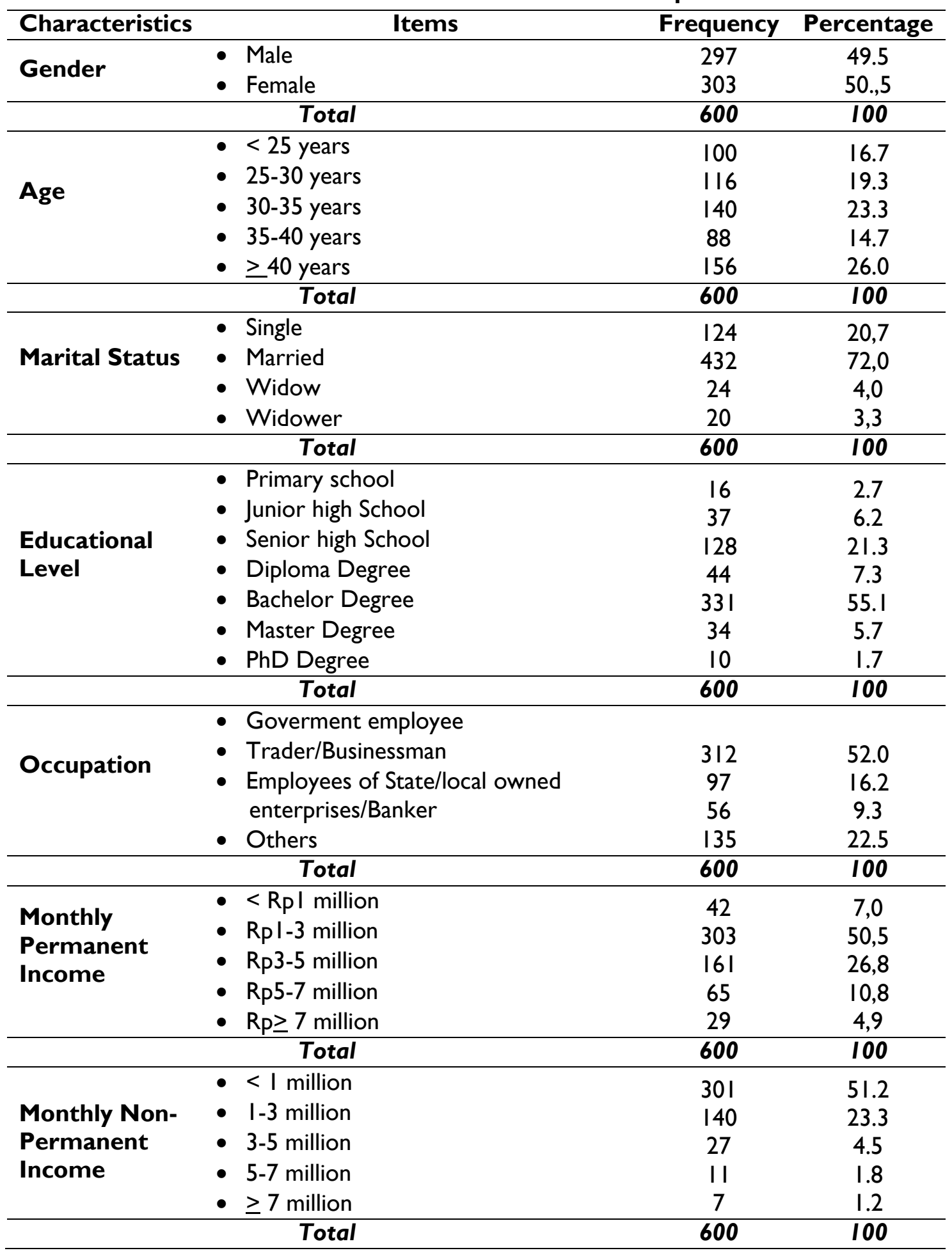


Pertaining to the variable of culture, as reported in Table 3 showed that the respondents perceived that "the payment of zakat is the duty of every Muslim" with the highest average score of 4.36. Meanwhile, the lowest average score of 3.36 was given on the statement "I understand that paying zakat is a habit/custom of our society". The mean score for this variable was 3.96, indicating that the culture is agreed as one of the important factors considering by the Muzakki in paying their zakat.

\begin{tabular}{lcc} 
Table 2: Paying Zakat via Baitul Mal (in Percentage) \\
\hline Question & Yes & No \\
\hline Have you ever paid zakat via Baitul Mal & 50 & 50 \\
\hline
\end{tabular}

Next, Table 4 reported the perception of the Muzakki on their motivation to pay zakat at the Baitul Mal, Aceh. On average, the religious factor has driven most of the respondents to pay zakat at the Baitul Mal Aceh. They were highly motivated to pay zakat, as it could clean their property from prohibited elements of income and souls from unnecessary spiritual illness with the highest average score of 4.63. Meanwhile, the lowest average score of 4.14 was given on the statement "I feel depressed if I have not fulfilled the obligation to pay zakat". The mean score for this variable was 4.37, showing that the motivation is highly agreed as one of the important factors considering by the Muzakki in paying their zakat at the Baitul Mal Aceh. Of the variables investigated in this study, motivation was found as the dominant variable (the highest score) that might affect the decision of the Muzakki to pay their zakat obligation at the Baitul Mal Aceh.

Table 3: Respondents' Perception on the Variable of Culture

\begin{tabular}{|c|l|c|c|c|c|c|c|}
\hline \multirow{2}{*}{ No } & \multicolumn{1}{|c|}{ Statement } & \multicolumn{5}{c|}{ Percentage } & \multirow{2}{*}{ Average } \\
\cline { 3 - 7 } & & SD & DA & UD & A & SA & \\
\hline I & $\begin{array}{l}\text { I understand that paying zakat is a } \\
\text { habit/custom of our society }\end{array}$ & 7.3 & 20.0 & 8.7 & 37.3 & 26.7 & 3.55 \\
\hline 2 & $\begin{array}{l}\text { I believe that the payment of zakat } \\
\text { is the duty of every Muslim }\end{array}$ & 0.0 & 0.0 & 1.3 & 26.7 & 72.0 & 4.70 \\
\hline
\end{tabular}


The Motivation of Muzakki...

M. Shabri Abd. Majid

\begin{tabular}{|c|l|c|c|c|c|c|c|}
\hline \multirow{2}{*}{ No } & \multicolumn{1}{|c|}{ Statement } & \multicolumn{5}{c|}{ Percentage } & \multirow{2}{*}{ Average } \\
\cline { 3 - 7 } & & SD & DA & UD & A & SA & \\
\hline 3 & $\begin{array}{l}\text { I believe that paying zakat is one of } \\
\text { the arts in helping other fellow } \\
\text { Muslims }\end{array}$ & 1.3 & 4.7 & 4.0 & 40.7 & 49.3 & 4.36 \\
\hline 4 & $\begin{array}{l}\text { I pay zakat as a part of my moral } \\
\text { responsibility }\end{array}$ & 0.7 & 0.7 & 10.7 & 47.3 & 40.7 & 4.28 \\
\hline 5 & $\begin{array}{l}\text { I pay zakat to avoid from being } \\
\text { penalized socially }\end{array}$ & 2.7 & 16.7 & 24.7 & 39.3 & 16.7 & 3.53 \\
\hline 6 & $\begin{array}{l}\text { I pay zakat as a part of my societal } \\
\text { culture }\end{array}$ & 6.7 & 21.3 & 18.0 & 38.7 & 15.3 & 3.36 \\
\hline \multicolumn{7}{|c|}{ Mean } \\
\hline
\end{tabular}

Table 5 reported the perception of the Muzakki on the regulation. Respondents strongly believed that Islam has regulated the zakat payment in its Qur'an, Hadith and the ljma' of Ulama with the highest score of 4.49 , followed by the existing provincial regulation (Qanun) on zakat with the score of 4.29. On the contrary, the lowest average score of 3.19 was given on the statement "Regulation of the zakat forces me to pay zakat, as if it is not fulfilled, I can be penalized". These Muzakki perceptions indicated that, to some extent, the decision of Muzakki to pay zakat at the Baitul Mal was more motivated by their obligation awareness on paying zakat rather than they were forced by an afraid of the existing regulation if they did not fulfilled their obligation, they would be penalised. Overall, the mean score for this variable was 3.87, indicating that the regulation was agreed as one of the pivotal factors considering by the Muzakki in paying their zakat at the Baitul Mal.

Table 4: Respondents' Perception on the Variable of Motivation

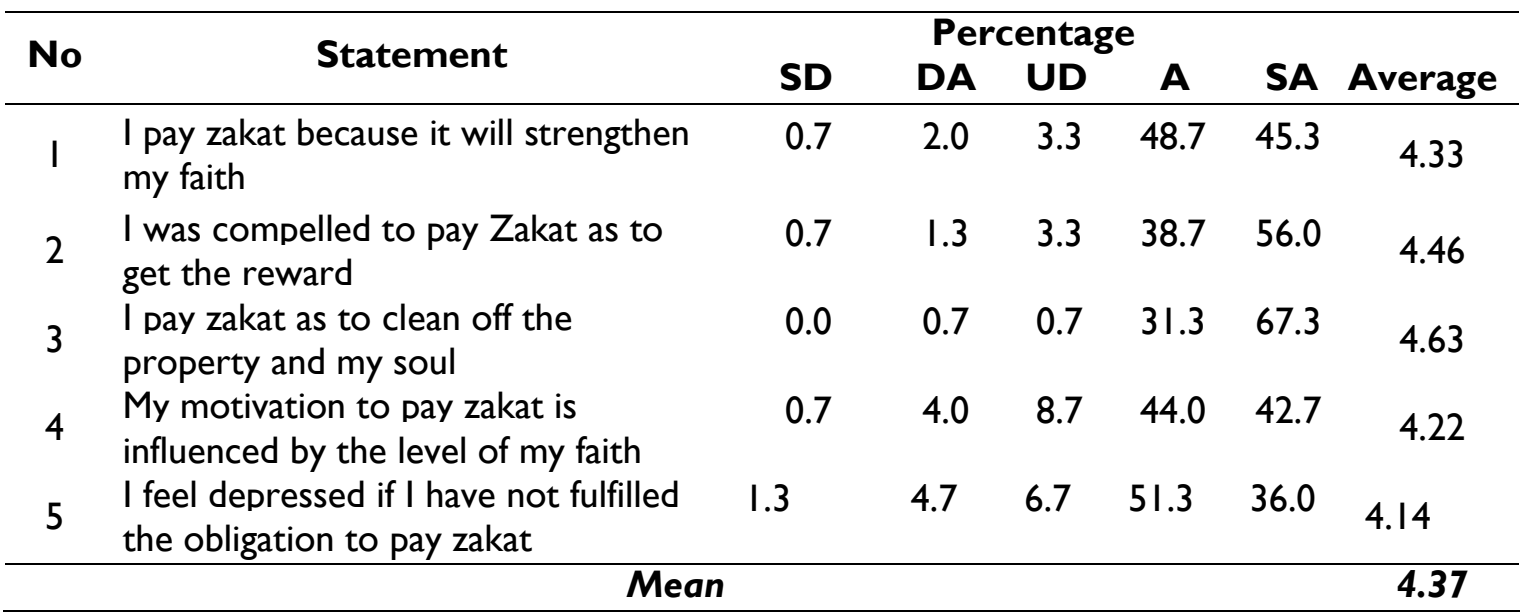


Finally, Table 6 reported the Muzakkis knowledge or understanding on zakat. 15 questions or statements were posed to the Muzakki to ensure their understanding or knowledge level on zakat obligation. Overall, the mean score for this variable was 3.63 , indicating that the knowledge or understanding on zakat was relatively lower. Comparing to other variables, the knowledge or understanding on zakat by Muzakki was found to be the lowest score. This could imply that the payment of zakat has been driven more by other variables such as culture and regulation. Specifically, of these I5questions or statements, their perception on "Nisab level of zakat for gold if it has reached 100 gram" was found to be the lowest average score by 2.33 . This could happen simply due to the most of the Muzakki have no experience of paying zakat for the gold. Meanwhile, the highest average score of 4.42 was given on the statement "I pay zakat if my property has reached the nisab level". These findings indicated that the Muzakki only have a general understanding on zakat, but they have no comprehensive understandings on entire zakatable items, such as zakat on jewellery, foods and animals.

Table 5: Respondents' Perception on the Variable of Regulation

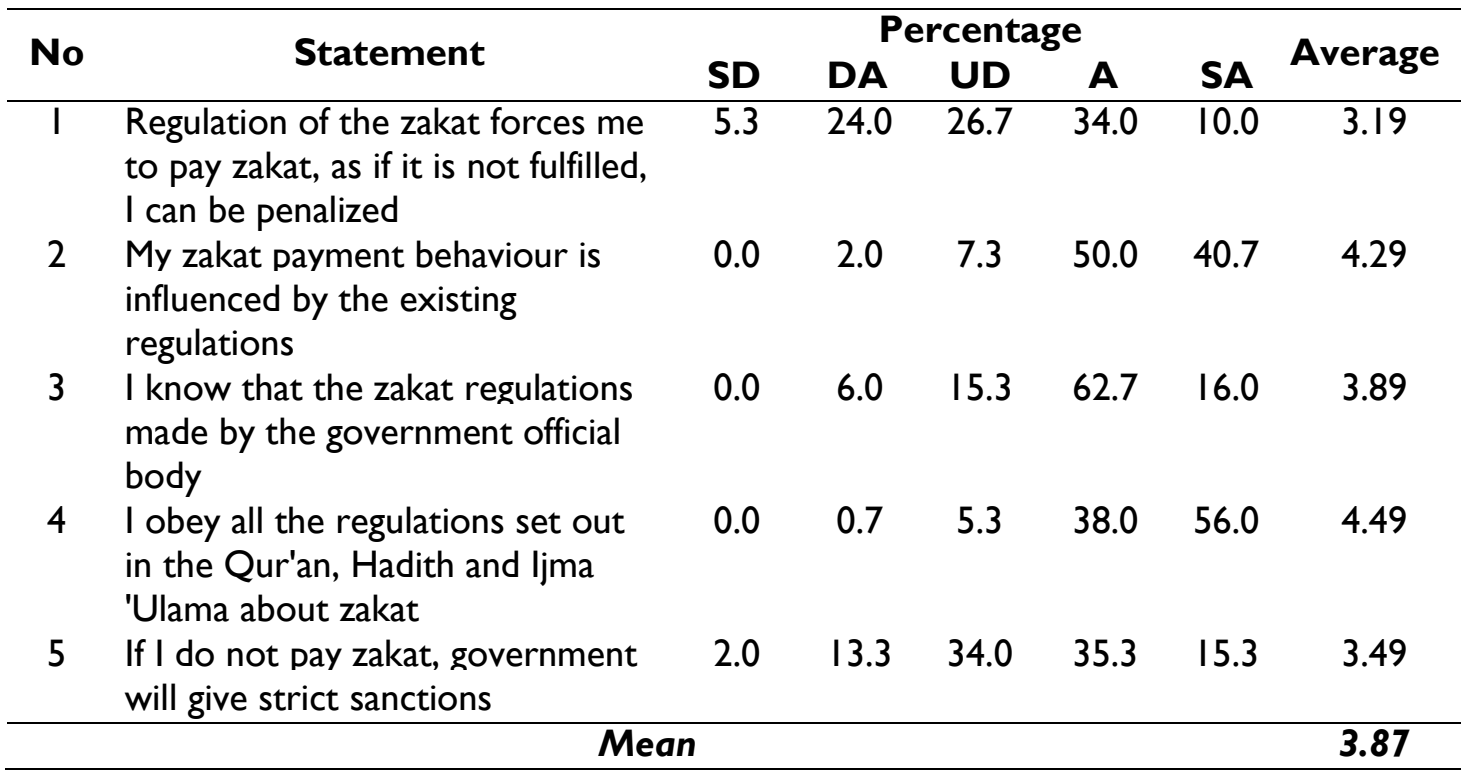

After all the variables studied were measured, then the next step is to empirically explore the factors affecting decision of Muzakki to pay zakat at the Baitul Mal Aceh using the multiple logistic regression models. However, before the study further analyses the effects of independent variables on the dependent variables, the validity and reliability are tested to ensure the accuracy of the instruments or 
The Motivation of Muzakki...

M. Shabri Abd. Majid

indicators in measuring the investigated variables and consistencies of the respondents' responses. We found that the score of Cronbach Alpha for all variables were above 0.60 , signifying that all variables were valid. In addition, all instruments were highly and significantly correlated with the values greater than 0.50 , indicating that all variables were reliable.

Furthermore, the study also tested the classical assumptions comprising tests of normality, heteroscedasticity, multicollineraity and autocorrelation. The study found that all variables were normally distributed and indicated by the insignificant values of the Kolgomorov-Smirnov test, where all their $p$-values were greater than 0.05 . As for the hetorescadicity test, the study also found that all variables were homoscdastic as showed by the P-Plot graphs where all values were scattered around the diagonal lines of the graphs. The study also found that the values of VIF were less than I0, indicating that all variables were free from the multicolinierity problem. Finally, the DurbinWatson values for all variables were around 2 , indicating that all variables were free from the autocorrelation problem. These findings indicated that all classical assumptions were fulfilled, thus all variables could be further empirically analysed to measure their influences on the decision of Muzakki to pay zakat at the Baitul Mal Aceh.

Table 6: Respondents' Perception on the Variable of Knowledge on Zakat

\begin{tabular}{clcccccc}
\hline No & \multicolumn{1}{c}{ Statement } & Percentage & & \multirow{2}{*}{ Average } \\
\hline I & $\begin{array}{l}\text { I pay zakat if my property has } \\
\text { reached the nisab level }\end{array}$ & 0.0 & 0.7 & 5.3 & 43.3 & 50.7 & 4.42 \\
2 & $\begin{array}{l}\text { Nisab level of zakat for gold is if it } \\
\text { has reached I00 grams }\end{array}$ & 4.0 & 10.7 & 20.0 & 47.3 & 18.0 & 2.33 \\
$3 \quad \begin{array}{l}\text { Nisab level for goat is if it has } \\
\text { reached 40 goats }\end{array}$ & 2.0 & 3.3 & 22.0 & 40.0 & 32.7 & 3.96 \\
$4 \quad \begin{array}{l}\text { Haul for zakat of gold is paid when } \\
\text { the gold is bought }\end{array}$ & 8.0 & 21.3 & 34.7 & 27.3 & 8.7 & 2.91 \\
5 & $\begin{array}{l}\text { Haul of zakat is a time limit of an } \\
\text { object to be paid zakat }\end{array}$ & 0.0 & 0.7 & 20.7 & 54.0 & 24.7 & 4.01 \\
6 & $\begin{array}{l}\text { Haul for zakat of paddy is when it } \\
\text { reaches one year }\end{array}$ & 4.7 & 14.7 & 26.7 & 42.0 & 12.0 & 2.56 \\
7 & $\begin{array}{l}\text { There are types of zakat, namely } \\
\text { zakat al-fitr and zakat al-mal }\end{array}$ & 2.7 & 1.3 & 6.7 & 51.3 & 38.0 & 4.19 \\
8 & $\begin{array}{l}\text { Zakat is not determined based on } \\
\text { its nisab level and haul }\end{array}$ & 12.0 & 26.0 & 22.0 & 31.3 & 8.7 & 3.00 \\
9 & $\begin{array}{l}\text { Zakat al-fitr is an obligation for } \\
\text { every Muslim }\end{array}$ & 0.7 & 0.7 & 3.3 & 26.7 & 68.7 & 4.60 \\
\hline
\end{tabular}




\begin{tabular}{clrrrrrr}
\hline No & \multicolumn{1}{c}{ Statement } & SD & DA & UD & A & SA & Average \\
\hline I0 & $\begin{array}{l}\text { Zakat for salary is up to 20\% of the } \\
\text { income level }\end{array}$ & 25.3 & 24.0 & 24.7 & 18.7 & 7.3 & 3.39 \\
I1 & $\begin{array}{l}\text { Zakat calculation in accordance } \\
\text { with the provisions sets out in the }\end{array}$ & 0.0 & 0.7 & 4.0 & 46.7 & 48.7 & 4.41 \\
$\begin{array}{l}\text { Qur'an, Hadith and ljma' } \\
\text { I2 }\end{array}$ & $\begin{array}{l}\text { Nisab level of Zakat for buffaloes is } \\
\text { if it has reached 2 buffaloes } \\
\text { Zakat is distributed to eight groups } \\
\text { of people (Mustahik) }\end{array}$ & 11.3 & 16.0 & 31.3 & 32.7 & 8.7 & 2.87 \\
14 & $\begin{array}{l}\text { Zakat is only required to be paid } \\
\text { by the rich }\end{array}$ & 20.0 & 44.7 & 11.3 & 19.3 & 4.7 & 3.54 \\
Baitul Mal is the most appropriate \\
avenue to pay as exemplified by the \\
\begin{tabular}{l} 
Prophet Muhammad (pbuh) \\
\multicolumn{1}{c}{ Mean }
\end{tabular} & 0.7 & 4.7 & 14.7 & 48.0 & 32.0 & 4.04 \\
\hline
\end{tabular}

Table 7 reported the findings from the multiple binary logistic regressions, which was showing the influences on the culture, motivation, regulation and knowledge on the decision of Muzakki to pay zakat at the Baitul Mal Aceh. Overall, the variables were found significantly and simultaneously affecting the decision of Muzakki to pay zakat at $1 \%$ significance level (sig. $=0.006$; Chisquare $=13.123$; Hosmer and Lemeshow Test $=12.122$; sig. 0.044). Furthermore, Negelkerke's $R^{2}$ with the value of $0.65 \mathrm{I}$, implied that the influences of culture, motivation, regulation and understanding of zakat was only able to explain the variation in decision of Muzakki to pay zakat by $65.1 \%$. These findings supported the earlier finding by Jahrotunasipah (2012) who documented that the cultural variables, motivation, regulation, and knowledge of zakat influenced the decision of government employees to pay zakat in the city of Cirebon. This finding further indicated that many other variables, which were not investigated in this study, might have significantly explained the variations of the decision of Muzakki to pay zakat at the Baitul Mal Aceh by 34.9\%. These variables were including zakat management, Trust on Baitul Mal, Baitul Mal's transparency and accountability in managing zakat, issue of zakat and tax, and many other political, economic, social aspects. 
The Motivation of Muzakki...

M. Shabri Abd. Majid

Table 7: Results of Multiple Logistic Regression

\begin{tabular}{|c|c|c|c|c|}
\hline Variable & B & Wald & Sig. & $\operatorname{Exp}(B)$ \\
\hline Constant & $2.765^{* * * k}$ & 1.675 & 0.010 & $1.51 \mathrm{I}$ \\
\hline Culture (CUL) & $0.513^{* * * *}$ & 2.023 & 0.002 & 1.576 \\
\hline Motivation (MOT) & $1.123^{* * * *}$ & 6.122 & 0.010 & 1.519 \\
\hline Regulation (REG) & $0.339^{* *}$ & 0.721 & 0.032 & 1.382 \\
\hline Knowledge (KZ) & $0.809^{* *}$ & 1.231 & 0.012 & 1.412 \\
\hline \multirow[t]{3}{*}{ Diagnostic tests } & \multicolumn{4}{|c|}{ Chi-squre $=13,123^{* * *} \quad($ sig $=0.006) ;$} \\
\hline & \multicolumn{4}{|c|}{ Hosmer \& Lemeshow Test ${ }^{* *}=12,122(\mathrm{sig}=0.044)$} \\
\hline & \multicolumn{4}{|c|}{ Negelkerke's R² $=0.65 \mathrm{I}$} \\
\hline
\end{tabular}

Based on the logistic regression's finding in Table 7, we could present in the estimated logistic regression function, as follows:

\section{$P Z=2.765+0.513 C U L+I . \mid 23 M O T+0.339 R E G+0.809 K Z$}

With regards to the partial influences of each variable on the decision of Muzakki to pay zakat at the Baitul Mal Aceh, the study found that all variables has positively and significantly affected the decision of Muzakki to pay zakat at the Baitul Mal Aceh. The motivation is found to be the dominant factor with the estimated value of I.I23, followed by knowledge (with the estimated value of 0.809 ), culture (with the estimated value of 0.513 , and regulation (with the estimated value of 0.809 ).

Apart from other variables, culture was found as one of the factors affecting decisions of Muzakki to pay zakat at the Baitul Mal. This finding further implied that the existing Islamic culture in Aceh should be preserved, so that it would not be assimilated with the western cultures. The findings of study proved that paying zakat is not just being a command of Allah in Islam, but it has become a culture in society. This finding supported the findings by Karsino (2009) and Jahrotunasipah (2012) who documented that culture has influenced the willingness of government employees to pay zakat from their salaries.

Furthermore, the motivation variable also found to be positive and significant in influencing the decision of Muzakki to pay zakat. That is, the higher the motivation, the higher their tendency to pay zakat at the Baitul Mal. Muzakki were motivated to pay 
zakat as they expected to gain rewards from Allah by contributing to other social beings as His servant. The results of this study were consistent with the study conducted by Jahrotunasipah (2012). Similar to other factors, regulation was also found positively and significantly influencing the decision of Muzakki to zakat at the Baitul Mal, findings similar to Karsino (2009); Jahrotunasipah (2012). Although, most of respondents perceived that failure to pay zakat might lead to social and governmental sanctions, but it seemed to be impractically implemented. In Article 4 paragraph (2) letter c of Law No. 18 of 200 I on special autonomy for the province of Aceh, this specified that the zakat's collection considered as part of the provincial government revenue (Pendapatan Asli Daerah, PAD). This regulation, however, has been a matter of controversy in practice, since the allotment of the zakat on eight recipient categories (Mustahik) was clearly mentioned in the Holy Qur'an. While the PAD according to Darise (2006) is local revenue earned by local regulations in accordance with the law, and these PADs were allocated to support the duties of governance and development projects in order to exercise the regional autonomy independence in Aceh. Thus, this has been contrary to the basic rules of the Holy Qur'an, which stated that zakat should only be distributed to the Mustahik and could not allocated to support the developmental projects of the government. Therefore, in matters of this regulation, the Government of Aceh should have a rational legal awareness in order to avoid such misunderstandings in the future.

In the Goverment of Aceh Act (Undang-Undang Pemerintahan Aceh, UUPA) No. II of 2006, Article 13 (I), I80 (I), 19I and 192, it has been regulated that the zakat payment would be considered as part of tax payment. In other words, this act regulated that zakat payment was considered as the tax-exempted; meaning that those who have paid zakat would reduced their tax obligation with the amount of zakat paid. Unfortunately, the act could not be executed completely, as it is against the central government regulation. This fact perceived by Muzakki as an unfair practice for Muslims, because apart from paying zakat, they must also pay taxes. In the near future, Muzakki are highly expected that zakat could be treated as the tax-exemption as has been practiced by the neighbouring country, Malaysia.

Finally, the knowledge or understanding of Muzakki on zakat obligation was also found to be one of important factors affecting the decision of Muzakki to pay zakat at 
The Motivation of Muzakki...

M. Shabri Abd. Majid

the Baitul Mal. This finding is very much in harmony with the study conducted by Huda and Ghofur (2012). That is, the higher the level of understanding on zakat, the tendency of Muzakki to pay zakat would also be higher. These understandings on zakat included the issues of nisab, haul, type of zakatable items, etc. The results of this study was consistent with Karsino (2009); Jahrotunasipah (2012). They found that knowledge on zakat has a positive and significant impact on the zakat payment.

The findings of this study provide the implications that in order to make Baitul Mal as the avenue of choice for Muzakki to pay zakat, the Islamic culture need not be enhanced and preserved, the existing regulation should be enhanced and enforced and the awareness of the Muzakki on their obligation to pay zakat need to be further improved. As the only province in Indonesia that has been granted by the central government to implement shariah law, the government of Aceh should promote the practices of Islam, including zakat. Zakat should be used as one of important fiscal policy to eradicate the poverty as well as promote the welfare of Acehnese in the province, where the poverty rate in Aceh is still higher as compared to the national poverty level. Last but not least, although, Acehnese were well known as the Muslim society, but their understanding of zakat should be further improved. This could be done through academic discussion forums, seminars and study groups about the Figh of Zakah, banners, pamphlets, brochures, and academic articles as well as popular writing on mass media and newspaper.

\section{CONCLUSION}

This study empirically explores the influences of culture, motivation, regulation and understanding on zakat on the decision of Muzakki (zakat payers) to pay zakat at the Baitul Mal Aceh, Indonesia using a multiple binary logistic regression. The study documented that culture, regulation, motivation, and understanding of the Muzakki on zakat significantly and positively affected the decision of Muzakki to pay their zakat at the Baitul Mal Aceh. This findings of the study implied that in order to make Baitul Mal as the choice avenue for Muzakki to pay their zakat, Islamic cultures should be preserved among Acehnese, government should enhance and enforce the existing zakat regulation (Qanun) (Baitul Mal Aceh, 2013) and the people of Aceh need to be equipped with the relevant knowledge on the obligation of zakat payment. 


\section{REFERENCES}

Ahira, A. (20/3). Arti Budaya. http://www.anneahira.com/arti-budaya.htm. Accessed in February 12, 2015.

Arif, R.M.N.A. (20I2). Efek Multiplier Zakat Terhadap Pendapatan di Provinsi DKI Jakarta. Al-lqtishad: Journal of Islamic Economics. Vol. 4, No. I: 52-66.

Asmuni, M. (2007). Zakat profesi dan upaya menuju kesejahteraan social. Jurnal Ekonomi Islam La_Riba. Vol. I, No. I: 43-56.

Baitul Mal Aceh. (20I3). Peraturan Pemerintah dan Qanun tentang Zakat. Banda Aceh: <http://baitulmal.acehprov.go.id/. Accessed in February I5, 2015.

BPS Provinsi Aceh. (2015). Aceh dalam Angka. BPS Provinsi Aceh, Banda Aceh.

Daliyo, J.B. et.al. (200I). Pengantar Ilmu Hukum: Buku Panduan Mahasiswa. Jakarta: Prenhalindo

Danim, S. (2004). Motivasi Kepemimpinan dan Efektivitas Kelompok. Jakarta: Rineka Cipta.

Daud, Z. et.al. (20I I). Model Perilaku Kepatuhan Zakat: Suatu Pendekatan Teori. Jurnal Iqtishoduna. Vol. 7, No. I: I-2I.

Firdaus, M. et.al. (20I2). Economic estimation and determinations of Zakat potential in Indonesia. Working Paper Serioes Jeddah: Islamic Research and Training Institute (IRTI). No. I433-07: I-74.

Huda, N. \& A. Ghofur. (20I2). Analisis intensi Muzakkî dalam membayar zakat profesi. Al-lqtishad: Journal of Islamic Economics. Vol. 4, No. 2: 2I8-240.

Huda, N. et.al. (20I4). Prioritas Solusi Permasalahan Pengelolaan Zakat di Propinsi Banten dan Kalimantan Selatan dengan Metode AHP. Al-lqtishad: Journal of Islamic Economics. Vol. 6, No. 2: 223-238.

Huitt, W. (200I). Motivation to Learn: an Overview. Educational Psychology Interactive. http://www.edpsycinteractive.org/topics/motivation/motivate. html. Accessed in January 142015.

IAI. (2008). Standar Akuntansi Keuangan. Jakarta: Salemba Empat.

Jahrotunasipah, I. (2012). Faktor-Faktor Yang Mempengaruhi Keputusan Pegawai Negeri Sipil (PNS) Di Lingkungan Pemerintah Daerah Kota Cirebon Untuk Membayar Zakat Profesi Melalui BAZ / LAZ Dengan Cara Pemotongan Gaji. http://ekospasca.blogspot.com/20I2/I2/faktor-faktor-yang-memengaruhi. html. Accessed in January 102015. 
The Motivation of Muzakki...

M. Shabri Abd. Majid

Karsino. (2009). Peluang Kesediaan Karyawan untuk Dipungut Zakat Profesi dengan Metode Withholding dan Faktor-Faktor yang Mempengaruhinya (Penelitian Terhadap Karyawan Swasta Di Jakarta). (Unpublished Thesis). Jakarta: Universitas Indonesia.

Malik, A. (2010). Konstruksi Sosial Kuasa Pengetahuan Zakat (Studi Kasus Tiga Lembaga Zakat di Provinsi Jambi dan Sumatera Barat). (Unpublished Dissertation). Bogor: Institut Pertanian Bogor.

Nurhasanah, N. (20I2). Zakat di Malaysia dalam perspektif kkonomi. Al-lqtishad: Journal of Islamic Economics, Vol. 4, Vol. I: 82-I 00.

Rahmawati, Y. (20II). Refleksi sistem distribusi syariah pada lembaga zakat dan wakaf dalam perekonomian Indonesia. Al-lqtishad: Journal of Islamic Economics. Vol. 3, No. I: $93-112$.

Rais, I. (2009). Muzakki dan Kriterianya Dalam Tinjauan Fikih Zakat. Al-lqtishad: Journal of Islamic Economics. Vol. I, No. I: 92-106.

Sahlan, E. (20II). Penelitian Zakat. Cirebon: STEI Al-Islah. http://www.scribd.com/ doc/49570525/PENELITIAN-ZAKAT-edisi-REVISI. Accessed February 28, 2015.

Suma, M. A. (20I3). Zakat, Infak, dan Sedekah: Modal dan Model Ideal Pembangunan Ekonomi dan Keuangan Modern. Al-lqtishad: Journal of Islamic Economics. Vol. 5, No. 2: 254-274. 